\title{
鉄筋腐食によって損傷を受けた RC ばりの挙動に関する考察 \\ THE BEHAVIOUR OF RC BEAMS DAMAGED BY CORROSION OF REINFORCEMENT
}

\author{
橘吉宏*・梶川康男**.川村満紀*** \\ By Yoshihiro TACHIBANA, Yasuo KAJIKAWA and Mitsunori KAWAMURA
}

\begin{abstract}
The mechanical behaviour of RC beams damaged by corrosion of reinforcement is not only experimentally but also theoretically studied using an elasto-plastic finite element method. In the experiments, loading and bond tests are conducted for RC specimens damaged with an accelerated galvanostatic corrosion method. It is found that the reduction in stiffness and load carrying capacity occured in the damaged beams. Theoretical studies are made to investigate the cause of the action of these damaged beams. From those experimental and theoretical considerations, it could be indicated that the mechanical behaviour of damaged beams is affected by inadequate transmission of stresses between reinforcement and concrete, which results from internal stresses and growth of cracks due to the formation of corrosion products.
\end{abstract}

Keywords : mechanical behaviour, RC beam, corrosion of reinforcement, FEM

\section{1. まえがき}

鉄筋腐食による $\mathrm{RC}$ 構造物の被害が各地で報告され るようになってきている1).これらの構造物中における 鉄筋の腐食は, 飛来塩分の浸透や中性化域の進行, また, 海砂使用や混和剤などによる打設時の塩分混入が主な原 因であるとされている2．そしてその被害形態として， 鉄筋の一部に断面欠損を生ずる例や，鉄筋が全体的に腐 食し鉄筋軸に沿ったひびわれや剝離が生ずる例が典型的 な被害例として報告されている。

このような腐食を受けた $\mathrm{RC}$ 構造物の安全性の評価 法として曲げ部材である RC ばりを例にとると，断面 欠損が耐力に及ぼす影響が支配的な場合においては，そ の断面欠損量をもとにして計算された曲げ耐力により安 全性を評価する方法が有効であると考えられる．他方， 鉄筋が全体的に腐食した RC 部材においては，鉄筋の さびによる断面欠損量が耐力に影響を及ぼさないような 程度の量であっても，腐食膨張力によりコンクリートに

* 正会員 工修 川田工業(株)技術本部中央研究室 ( ₹114 北区滝野川 1-3-11)

** 正会員 工博 金沢大学教授 工学部土木建設工学科 （テ920 金沢市小立野 2-40-20）

*** 正会員 工博 金沢大学教授 工学部土木建設工学科 (同上)
鉄筋軸方向のひびわれの発生や鉄筋の付着劣化が生じ, これらに伴った耐力の低下や破壊形式の変化の生ずる可 能性のあることが実験的に示されている ${ }^{3)-7)}$. しかしな がら,さびの程度と劣化挙動や耐力との関係はいまだに 不明な点が多く, 安全性の検討を行ううえでの判断材料 として, それらの解明が必要であろうと考えられる.

本研究はこのような観点から， RC 部材として曲げを 受ける単鉄筋単純ばりを考え, 実験的な手法に加えて解 析的な手法により，鉄筋腐食によって損傷を受けた $\mathrm{RC}$ ばり（以下「腐食 RC ばり」と称す）の劣化機構の推 定を行い, それらの関係の解明を試みたものである. 実 験的手法としては，鉄筋が全体的に腐食した RC ばり のモデル化として, 外部電流の印加により腐食させた(以 下「電食」と称す) RCばりを用いて, 載荷試験および 鉄筋の付着試験を実施し，その劣化挙動に対する検討を 行った. その結果, 腐食 RC ばりが劣化挙動を示す要 因亡して，鉄筋の最大付着力の低下，さびによる膨張圧 で生ずる内部応力の発生や鉄筋軸方向のひびわれ，およ びそれに伴う鉄筋への応力伝達の欠如のあることを示し た.しかし，実験で示された各要因が，腐食 RCばり の挙動に大きな影響を及ぼしているのか，それとも二次 的なものであるのかを実験結果だけから判断するのは容 易ではない. そこで解析的手法として, 有限要素弾塑性 
解析を用いて各要因に対する検討を行い，腐食 RC ば りの解析モデルと劣化機構について, 力学的な視点に 立った考察を行った。

本文は，これらの検討結果を報告し，腐食 RC ばり の安全性の検討を行ううえでの一判断資料を与えるもの である。

\section{2. 腐食 RC ばりの劣化挙動試験}

鉄筋が全体的に腐食した RC ばりを対象に，4.で行 われる解析的な検討結果と対比させることを目的とし て, 電食により劣化させた $\mathrm{RC}$ ばり供試体について載 荷試験と鉄筋の付着強度試験を行い，その劣化挙動につ いて検討を行った.

\section{（1）供 試 体}

載荷試験に用いた $\mathrm{RC}$ ばり供試体は，構造的に最も 単純なスターラップを有しない単鉄筋単純ばりとし, 鉄 筋の定着については鉄筋の付着力によって定着するもの とした．この RC ばり供試体の概要を支点位置および 載荷位置とともに Fig. 1 に示す. せん断スパン比 $(a / d)$ は曲げ破壊を呈するように 4.2 を設定し，使用した鉄筋 は黒皮付異形棒鋼D16（SD 30）で鉄筋比は $1.3 \%$ であ る. また，コンクリートの配合は Table 1 に示す.コン クリートは試験時において材令は約 2 か月であり, 圧縮 強度は $35.6 \mathrm{MPa}\left(363 \mathrm{kgf} / \mathrm{cm}^{2}\right)$, 引張強度は $3.2 \mathrm{MPa}$ $\left(33 \mathrm{kgf} / \mathrm{cm}^{2}\right)$, ポアソン比 0.18 , 初期弾性係数は 2.65 $\times 10^{4} \mathrm{MPa}\left(2.70 \times 10^{5} \mathrm{kgf} / \mathrm{cm}^{2}\right)$ であった．鉄筋につい ては，降伏強度が $353 \mathrm{MPa}\left(3600 \mathrm{kgf} / \mathrm{cm}^{2}\right)$ ，ヤング率 は $2.06 \times 10^{5} \mathrm{MPa}\left(2.10 \times 10^{6} \mathrm{kgf} / \mathrm{cm}^{2}\right)$ であった．引き 抜きによる付着強度試験において使用した供試体の概要 を Fig. 2 に示す。ここで供試体の断面は，RC ばり供試 体の腐食状態と同じ条件となるように， RC ばり供試体 と同一のものとした。

\section{(2) 電食試験}

腐食促進法としては，文献 3）を参考として定電流電 源による電食法を用いた。この方法は，Fig. 3 に示すよ
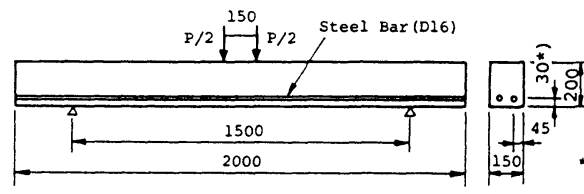

*) Side Cover (mm)
Fig. 1 RC Beam Specimen.

Table 1 Mix Proportion of Concrete.

\begin{tabular}{lccccc}
\hline $\begin{array}{l}\text { Nominal } \\
\text { Strength } \\
(\mathrm{MPa})\end{array}$ & Slump & $\begin{array}{l}\text { Maximum Size } \\
\text { of Coares } \\
\text { Aggregate } \\
(\mathrm{cm})\end{array}$ & $\begin{array}{c}\text { Air } \\
\text { Content }\end{array}$ & $\begin{array}{c}\text { Water } \\
\text { Cement } \\
\text { Ratio } \\
(8)\end{array}$ & $\begin{array}{l}\text { Sand } \\
\text { Percentage }\end{array}$ \\
\hline 20.6 & 8.0 & 25 & 4.0 & 59.0 & (8) \\
\hline
\end{tabular}

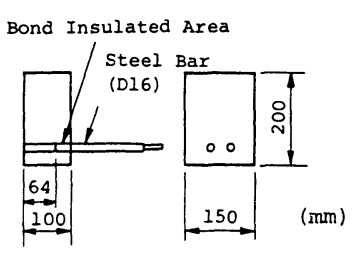

Fig. 2 Pull-Out Test Specimen.

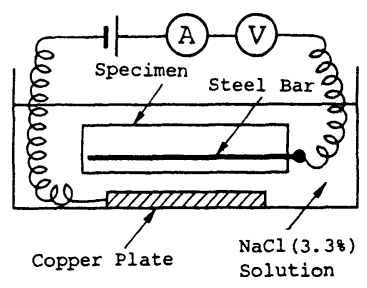

Fig. 3 Galvanostatic Corrosion System.

うに鉄筋を強制アノード溶解させる方法であり，必ずし も自然腐食と同一の腐食状況に対応するとは限らない. しかし，本研究で対象とした全体的に鉄筋が腐食した $\mathrm{RC}$ ばり供試体の力学的挙動に対する基礎的な検討を行 う範囲であれば，電食法による腐食のモデル化でも適用 が可能であると思われる.この電食法による腐食程度は, 積算電流量すなわち通電日数を変化させることにより調 整ができる. 本研究においては, 電流密度 $0.5 \mathrm{~mA} / \mathrm{cm}^{2}$ とし，通電日数を 0 日間 (非腐食), 3 日間 $(36 \mathrm{~mA} \cdot \mathrm{hr} /$ $\left.\mathrm{cm}^{2}\right), 6$ 日間 $\left(72 \mathrm{~mA} \cdot \mathrm{hr} / \mathrm{cm}^{2}\right), 10$ 日間 $\left(120 \mathrm{~mA} \cdot \mathrm{hr} / \mathrm{cm}^{2}\right)$, 15 日間 $\left(180 \mathrm{~mA} \cdot \mathrm{hr} / \mathrm{cm}^{2}\right)$ で鉄筋を電食させた $\mathrm{RC}$ ば り供試体を利用した。なお，15 日間通電の鉄筋の断面 欠損率は，10\%クエン酸 2 アンモニウム溶液を用いた さびの除去前と後の重量変化から測定した結果，約 $5 \%$ であった。

ここで, 通電に伴う RC ばり供試体の劣化状況とし て，15日間通電後の状況を Fig. 4 ～Fig. 6 に示す.

Fig. 4 は，鉄筋の腐食膨張圧によって RC ばり下面に発 生した鉄筋軸方向の繸ひびわれであり, 最大ひびわれ幅 は $0.75 \mathrm{~mm}$ であった. Fig. 5 は, 載荷試験後のはっり

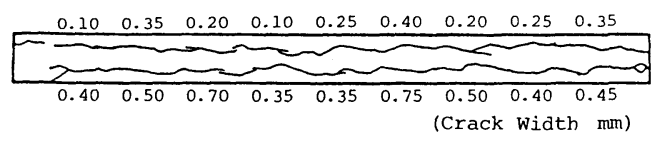

Fig. 4 Growth of Cracks after 15-days Current Period.

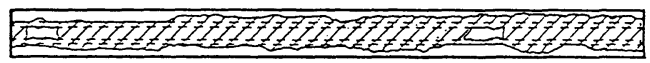

QDD Rust sludge Area

Fig. 5 Rust Sludge Area after 15-days Current Period. 


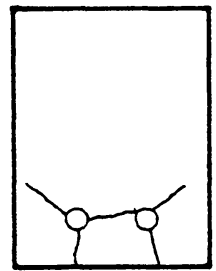

Fig. 6 Growth of Cracks after 15-days Current Period.

調査により確認されたさび汁の滲出域であり, Fig. 6 は, さび汁の滲出から判断された断面方向のひびわれの進展 である．また電食終了後の側面の一部にさび汁の滲出が みられたことからも, 膨張圧によって生ずる縦ひびわれ は RC ばりの下面ばかりでなく側面へ連なるようにも 進展していることがわかる.

一方, 引き抜き試験供試体についても RC ばり供試 体亡同梯の腐食条件となるようにした。すなわち，境界 条件を同一とするために，電食中は端面のコーティング を行い, また電流密度および通電日数も同一として電食 を行った。

\section{（3）載荷試験}

電食により劣化させた RC ばり供試体について載荷 試験を実施した。 その概要を Fig. 7 に示す. 図中に示し た荷重分配横ばり（Load distribution beam）は文献 8) を参考にして荷重一たわみ関係において耐力点以降の挙 動も追跡できるように設置したものである．なお，載荷 試験は供試体を電食終了後 3 日間室内で乾燥させた後に 行った.

載荷試験結果として, ひびわれ形状を Fig. 8 に, 荷 重一スパン中央たわみ関係を Fig. 9 に, また耐力を Table 2 に示す.

Fig. 8 に示すひびわれ形状をみてもわかるように，明

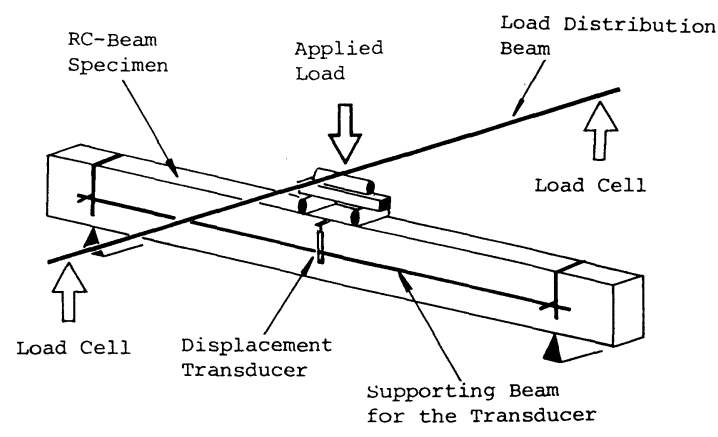

Fig. 7 Loading Test.
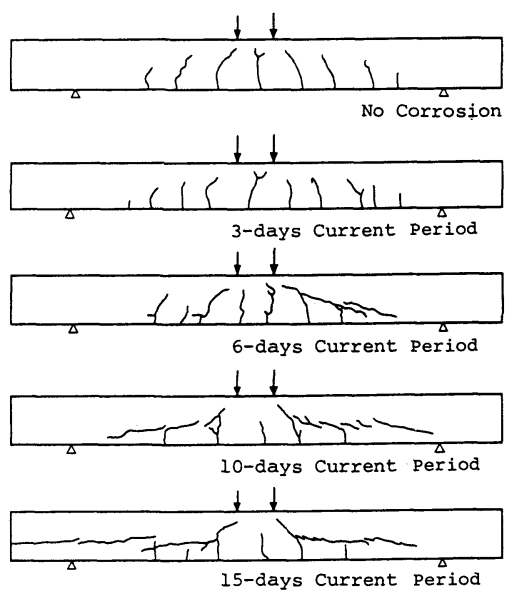

Fig. 8 Crack Pattern at Failure.

らかに非腐食の場合と電食ばり供試体の場合とでは破壊 形式が異なることがわかる.このような $\mathrm{RC}$ 部材の耐 力は破壊形式により大きく異なり，一般に，せん断破壊 の場合は曲げ破壊に比べ，十分な䩲性を確保できないば かりか耐力も低下するといわれている. 今回の載荷試験

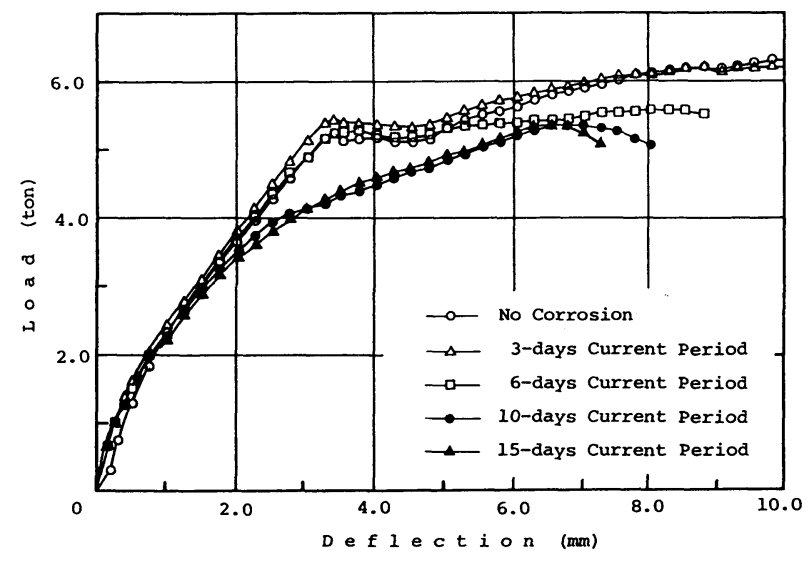

Fig. 9 Load-Deflection Relation. 
Table 2 Summary of Results for Loading Test.

\begin{tabular}{|c|c|c|c|c|c|c|}
\hline Specimen & $\begin{array}{l}\text { Current } \\
\text { Period } \\
\left(0.5 \mathrm{~mA} / \mathrm{cm}^{2}\right)\end{array}$ & $\begin{array}{l}\text { Crack } \\
\text { Width } \\
\text { (mu) }\end{array}$ & $\begin{array}{l}\text { Steel } \\
\text { Yield } \\
\text { Load } \\
\text { (ton) } \\
\end{array}$ & $\begin{array}{l}\text { Load Carr } \\
\text { Capacity } \\
\text { (ton) }\end{array}$ & $\begin{array}{l}\text { ying } \\
\text { Average } \\
(\text { )-Rate }\end{array}$ & $\begin{array}{l}\text { Failure } \\
\text { Type }\end{array}$ \\
\hline $\begin{array}{l}0-A \\
0-B \\
0-C \\
\end{array}$ & $\begin{array}{l}\text { No } \\
\text { Corrosion }\end{array}$ & $\begin{array}{l}-- \\
-- \\
\end{array}$ & $\begin{array}{l}5.04 \\
5.38 \\
5.19 \\
\end{array}$ & $\begin{array}{l}6.00 \\
6.52 \\
6.33 \\
\end{array}$ & $\begin{array}{c}6.29 \\
(1.00)\end{array}$ & Flexure \\
\hline $\begin{array}{l}3-\mathrm{A} \\
3-\mathrm{B} \\
3-\mathrm{C} \\
\end{array}$ & 3-days & $\begin{array}{l}-- \\
-- \\
\end{array}$ & $\begin{array}{l}5.36 \\
5.24 \\
5.92 \\
\end{array}$ & $\begin{array}{l}6.18 \\
6.16 \\
6.45 \\
\end{array}$ & $\begin{array}{c}6.26 \\
(1.00)\end{array}$ & Flexure \\
\hline $\begin{array}{l}6-A \\
6-B \\
6-C \\
\end{array}$ & 6-days & $\begin{array}{l}0.10 \\
0.10 \\
0.10\end{array}$ & $\begin{array}{l}5.09 \\
5.40 \\
5.32 \\
\end{array}$ & $\begin{array}{l}5.65 \\
5.53 \\
5.73 \\
\end{array}$ & $\begin{array}{c}5.64 \\
(0.90)\end{array}$ & $\begin{array}{l}\text { Shear - } \\
\text { Compression }\end{array}$ \\
\hline $\begin{array}{l}10-A \\
10-B \\
10-C\end{array}$ & 10-days & $\begin{array}{l}0.45 \\
0.65 \\
0.45\end{array}$ & $\begin{array}{l}5.16 \\
-- \\
--\end{array}$ & $\begin{array}{l}5.71 \\
5.37 \\
4.96\end{array}$ & $\begin{array}{c}5.35 \\
(0.85)\end{array}$ & $\begin{array}{l}\text { Bond - } \\
\text { Shear }\end{array}$ \\
\hline $\begin{array}{l}15-A \\
15-B\end{array}$ & 15-dayss & $\begin{array}{l}0.75 \\
0.50\end{array}$ & $=$ & $\begin{array}{l}5.60 \\
5.45\end{array}$ & $\begin{array}{c}5.55 \\
(0.88)\end{array}$ & $\begin{array}{l}\text { Bond - } \\
\text { Sheax }\end{array}$ \\
\hline
\end{tabular}

では，非腐食ばりは曲げ破壊であるのに対し，10日間 および 15 日間電食ばりは付着せん断破壊であった。ひ

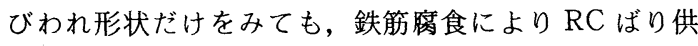
試体が劣化していることが推測される.

腐食程度によりに゙のように挙動が変化してゆくかを Fig. 8, 9, Table 2 の結果から考察を行えば，まず非腐 食および 3 日間電食ばり供試体はほぼ同様の挙動を示 し, 鉄筋降伏による曲げ破壊を生じているが, Fig. 9 か らわかるように，3 日間電食ばり供試体の方が非腐食ば り供試体に比べて初期の曲げ剛性は若干高いようであ る．また，6 日間電食ばり供試体は，鉄筋が降伏するま では 3 日間電食ばり供試体と同様の挙動を示すが，鉄筋 降伏後にせん断ひびわれが発生している.さらに，10 日間電食と 15 日間電食ばり供武体はほぼ同様の挙動を 示しており, 荷重の増加に伴い曲げ剛性が大きく減少し, 鉄筋に沿って $10^{\circ} \sim 20^{\circ}$ の傾きをなすひびわれが発生し て付着せん断破壊を生じている。 また, 最大耐力も非腐 食ばり供試体に比べて 10〜15％低くなった。このよう な耐力の低下は，曲げ破壊との破壊形式の相違から，断 面欠損量では説明できないことがわかる.

魚本ら ${ }^{3)}$, 武若ら ${ }^{4)}$, Mirsa $ら^{61}$ が行った種々の形式の 電食 RC ばり供試体における既往の実験結果のうちか ら, 本研究で対象とした非腐食時には曲げ破壊を呈する 単鉄筋単純ばりだけについて着目し比較を行うと，いず れの場合についても共通して電食による耐力の低下が報 告されており，本実験における結果と一致しているとい えよう.しかし，非腐食時には曲げ破壊を呈する単純ば りでも複鉄筋でスターラップを有するものについては, 耐力低下が必ずしも認められないことが報告されてお $り^{4), 6)}$, これらの挙動を含めて検討を行う必要がある.

\section{（4）付着強度試験}

鉄筋の付着強度試験として用いた引き抜き試験は, 鉄 筋とコンクリートの摩擦, 粘着および機械的なかみ合い の劣化を調べるためのものであり，Fig. 10 にその概要 を示す。一般に引き拢け時の付着破壊は瞬時に生ずるた めに, 鉄筋自由端変位と荷重の計測は, Fig. 10 に示す

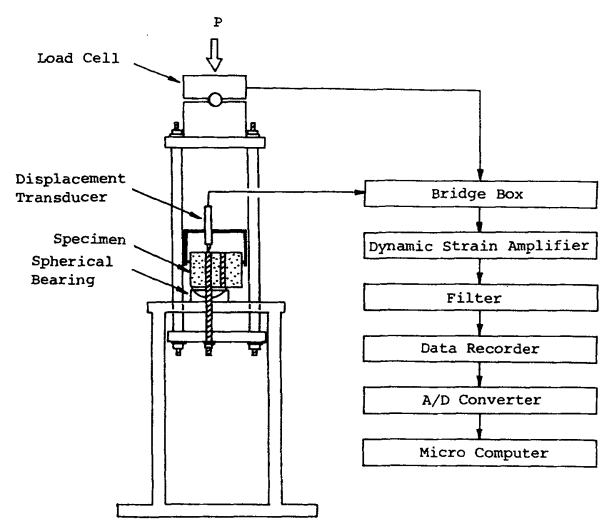

Fig. 10 Pull-Out Test.

ように動的な計測によった。なお，供試体数は，各通電 日数ごとに 5 体作成し試験を実施した.

引き抜き試験結果として, 代表的な付着応力度と自由 端すべり量の関係を Fig. 11 に示す.ここで付着応力度 とは,引き抜き力を鉄筋の付着周面積で割った值である. このような引き抜き試験方法では，断面においてせん断 力が作用していないために RC ばりの中での付着強度 と対応していないことが指摘されているが9)，上述した ような付着の劣化を調べるには有効な試験方法であると 思われる.このような鹰食鉄筋の最大付着力については, 森永 ${ }^{10)}$ が押し抜き法で行った試験では低下しないことが 報告されているが, 本試験結果によると, 最大付着力は さびの膨張圧によって生ずる縦ひびわれ発生後はさびの 程度により減少した．また, 初期の剛性については縦ひ びわれの有無にかかわらず上昇している．このような付 着の劣化挙動に及ぼす要因として, 腐食膨張圧による鉄 筋の拘束, 膨張圧に伴う縦ひびわれの発生, 腐食による 異形鉄筋の断面形状変化などによる影響が考えられる。

また，電食により側面に連なる縦ひびわれが発生した ことから，上述した引き抜き試験とは別に，縦ひびわれ

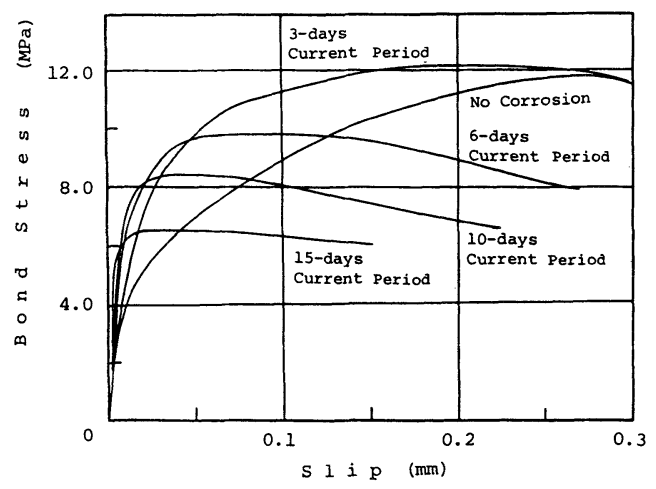

Fig. 11 Bond Stress-Slip Relation. 
が鉄筋の付着に及ぼす影響を調べた。すなわち，Fig. 12 に示す供試体 3 体について電食によるひびわれを RC ばり供試体と同様に発生させ，その後に Fig. 13 に示す せん断試験を実施した。このような試験方法は，ひびわ れ面のような不連続面を有する場合について有効な方法 であると思われる.その結果得られたひびわれ面におけ るせん断強度は $0.58 \mathrm{MPa}\left(5.9 \mathrm{kgf} / \mathrm{cm}^{2}\right)$ であり，コン クリートのせん断強度（一般に圧縮強度の $1 / 4 \sim 1 / 7$ ) に比べるとかなり小さな值であった. したがって, 本試 験結果から，この縦ひびわれにより鉄筋とコンクリート 間で応力伝達の欠如を生ずることがわかった.

\section{（5）腐食 RC ばりの性状変化}

鉄筋腐食により変化した性状をここでまとめておく. 引き抜き試験結果からは, 鉄筋腐食により最大付着力は 低下しており, 腐食 RC ばりの挙動に及ぼす影響が考 えられる. またさびの膨張圧に起因する性状の変化とし て, 鉄筋円周方向の内部応力の発生や, 縦ひびわれの発 生およびそれに伴う鉄筋とコンクリート間の応力伝達の 欠如のあることが示され，これらが及ぼす影響も考えら れる. しかし，以上に示したような劣化性状が腐食 RC ばりの挙動に大きな影響を及ぼしているのか，それとも 二次的なものであるのかを本研究で行った実験結果だけ から判断することは困難である. そこで, 有限要素弾塑 性解析を用いて各要因に対する解析的な検討を行うこと にした。

\section{3. 有限要素弾塑性解析法}

ここでは, 有限要素弾塑性解析法の概要についての説 明を述べる。
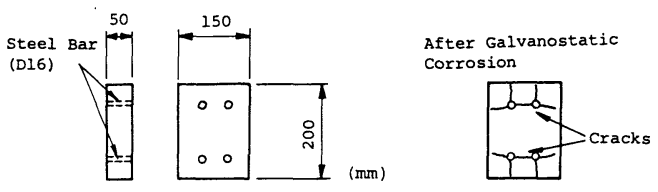

Fig. 12 Punching Shear Test Specimen.

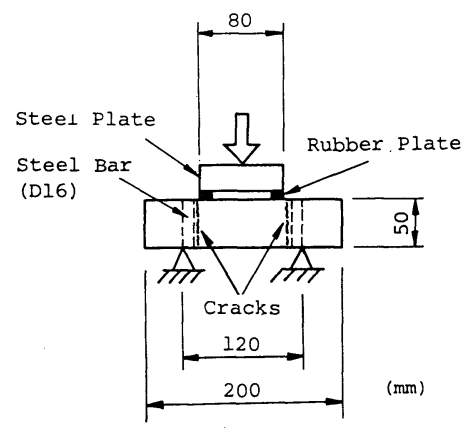

Fig. 13 Punching Shear Test.

\section{（1）コンクリートおよび鉄筋要素}

材料のモデル化として, コンクリートの構成式には塑 性理論に基づいたChen らのモデル11)を用い, 破壊規準 もそれに準じさせた. Chen らのモデルは，コンクリー 卜を等方性体であると仮定し, 塑性ポテンシャルと降伏 関数とが一致する関連流動則によるモデルであり, その 特徴は, コンクリートの挙動をより実際に適するように 表現するために, 降伏関数および破壊基準を圧縮域と引 張域とでそれぞれ別々の規準を設けていることである. また，ひびわれに対しては，ひびわれの破壊規準に到達 した要素内に引張主応力方向に連続的なひびわれを生じ ると仮定し, 構造物の全体的な挙動傾向を追跡するに適 している Smeared Cracking Model を用いることとし た。

他方，鉄筋についても，塑性理論に基づいた関連流動 則によるモデルを用い, 降伏関数は等方性金属材料の降 伏条件として一般的な von Mieses の降伏条件 ${ }^{12)}$ とし た。

なお,使用した有限要素は定ひずみ三角形要素であり， Fig. 14 に示す要素分割で解析を行った. またコンクリー 卜および鉄筋要素の材料諸定数は 2. で示した材料試験 で得られた值から決定した。

\section{（2）コンクリートから鉄筋への応力伝達要素}

鉄筋の腐食により，コンクリートに縦ひびわれを生じ させたり，また付着強度を低下させるなど，鉄筋周囲部 が弱点部となることが実験によって示された。したがっ て，その近傍におけるコンクリートから鉄筋への応力伝 達のモデル化が RC ばりの劣化挙動を追跡するうえで 重要な役割を果たすものと考えられる．この劣化部にお けるコンクリートから鉄筋への応力伝達を表現する要素 として，本解析においてはFig. 15 に示すGoodman ら の接合要素 ${ }^{13)}$ (仮想要素厚 $t=0.2 \mathrm{~cm}$ ) を適用すること としたここような接合要素を導入することにより，鉄 筋の引き抜き試験から得られた付着の劣化特性を $\mathrm{RC}$ ばり供試体の載荷試験の数值解析に反映させることがで き，また，縦ひびわれによる鉄筋への応力伝達の欠如を 表現した解析も可能となる.

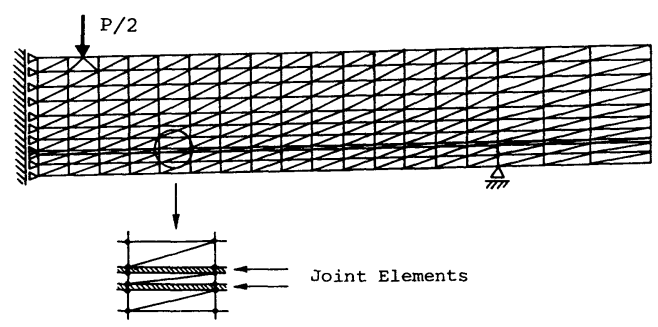

Fig. 14 Finite Elements for the RC Beam Specimen. 


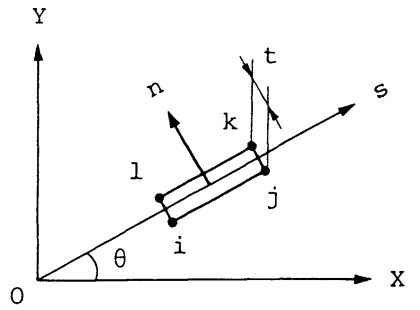

Fig. 15 Joint Element ${ }^{13)}$.

ここに適用した Goodman らの接合要素は, 要素剛性 が応力ーひずみ関係で取り扱われているのでその構成関 係を論ずることができるという利点をもっており，著者 らは前にこの要素を骨材とモルタルとの接合要素に適用 して，コンクリート構造モデルを解析し実験結果と対比 させて良好な結果を得ている ${ }^{144}$.この接合要素は，コン クリートや鉄筋に用いた定ひずみ三角形要素に適合する ものであり, 応力成分としてせん断応力成分, 直応力成 分およびモーメント成分を取り扱っているが，ここでは 前 2 者のみを取り扱うこととした，すなわち，接合要素 における剛性は次式で具体的に表わされることになる.

$$
\left[\begin{array}{l}
\tau \\
\sigma
\end{array}\right]=\left[\begin{array}{cc}
K_{s} & 0 \\
0 & K_{n}
\end{array}\right]\left[\begin{array}{l}
\gamma \\
\varepsilon
\end{array}\right]
$$

したがって式（1）から，直応力成分である $\sigma-\varepsilon$ 関係 における剛性 $K_{n}$ に関しては完全付着に相当するばね剛 性の值が用いられ，一方世ん断応力成分である $\tau-\gamma$ 関 係における剛性 $K_{s}$ については，上述に示したおのおの の付着劣化要因と電食日数に応じた関係が決定される必 要があることは明らかである.

なお，接合要素は，Fig.14に示すようにコンクリー トと鉄筋との間に挿入した。

\section{（3） 解 析 法}

弾塑性解析は，荷重増分解析により行った。それぞれ の荷重増加ステップにおいて各要素の状態を調べ，もし 破壊規準に達した要素があれば応力の解放を行い, 解放 力による他の要素の破壊がなくなるまでこれを繰り返し た. なお，連立一次方程式の解法として共役傾斜法を用 いた。

また，解析では，スパン中央変位が約 $6 \mathrm{~mm}$ となるま での増分解析を行い, 実験結果との比較を行うこととし た。

\section{4. 解析による劣化要因の推定}

前章で示した有限要素解析法を用いて，2. で示され た鉄筋腐食により変化した性状が，腐食 RC ばりの挙 動に及ぼす影響について検討した。これらの性状の変化 は鉄筋の引き抜き試験に基づいた付着劣化，さびの膨張 圧によって生ずる内部応力および縦ひびわれによる応力
伝達の欠如である．以下に，解析における劣化性状の取 り扱いについて説明し，非將食 RC ばり供試体と 15 日 間電食 RC ばり供試体の載荷試験を対象として検討を 行った結果について述べる.

\section{（1）解析における劣化性状の取り扱い}

解析では，引き抜き試験で評価される鉄筋とコンク リートの摩擦，粘着および機械的なかみ合いの劣化は, 接合要素の特性を変化させることにより表現でき,さび の膨張圧によって生ずる内部応力は初期応力により，ま た縦ひびわれによる応力伝達の欠如は同様に接合要素の 特性を変化させることにより表現できる.ここでは，実 験によって示されたおのおのの付着劣化性状と接合要素 の特性との対応および内部応力状態之初期応力の取り扱 い法について説明する.

a) 接合要素の特性との対応 引き抜き試験に基づ く付着劣化は, 式 $(1)$ における $\tau-\gamma$ 関係を鉄筋の付 着応力とひずみの関係とみなすことにより表現ができ る.この場合，奥行き方向の接合要素の厚さは鉄筋周長 に相当する値で決定される. 付着要素の剛性 $K_{s}$ の評価 法については, 従来は引き抜き試験の結果得られるマク 口的な付着力ーすべり量関係から算定するのが一般的で ある. しかし，引き抜き試験から得られる付着力-すべ り量関係がそのまま接合要素の付着応力ーひずみ関係を 評価しているとは必ずしもいえない，そこで，本研究で は, 引き抜き試験結果の有限要素法による逆解析からそ の関係を決定する手法を考え，電食日数に対応する剛性 を決定することとした．逆解析は Fig. 16 に示す要素分 割で行い，接合要素における $\tau-\gamma$ 関係を次式による指 数型の曲線 (Fig. 17 参照) で仮定した.

$$
\tau=\tau_{\max }\left(1-\exp \left(-\frac{G}{\tau_{\max }} \gamma\right)\right) \text {. }
$$

ここに $\tau_{\max }$ は付着強度であり， $G$ は Fig. 17 に示す $\gamma=$ 0 における接線剛性である. したがってこの曲線の傾き により付着剛性 $K_{s}$ が決定され，ひずみ $\gamma$ によって変化 する値となる。このような手法により決定した定数は, 非腐食に対して $G=490 \mathrm{MPa}\left(5000 \mathrm{kgf} / \mathrm{cm}^{2}\right) ， \tau_{\max }=$ $11.8 \mathrm{MPa}\left(120 \mathrm{kgf} / \mathrm{cm}^{2}\right)$ であり，15 日間電食に対して $G=980 \mathrm{MPa}\left(10000 \mathrm{kgf} / \mathrm{cm}^{2}\right), \quad \tau_{\max }=6.4 \mathrm{MPa}(65$

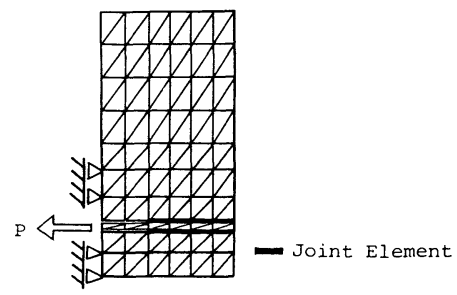

Fig. 16 Finite Elements for the Pull-Out Test Specimen. 


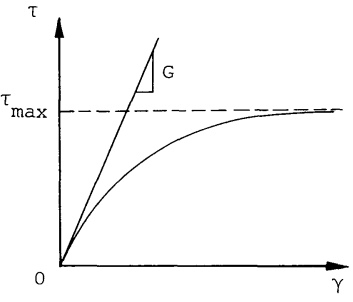

Fig. 17 Proposed Relation Between $\tau$ and $\gamma$.

$\left.\mathrm{kgf} / \mathrm{cm}^{2}\right)$ である.ここで，その逆解析結果を Fig. 18 に 示す．なお，直応力成分である $\sigma-\varepsilon$ 関係において $K_{n}$ は 完全付着に相当する值として $4900 \mathrm{MPa}$ (50 $000 \mathrm{kgf}$ / $\left.\mathrm{cm}^{2}\right)$ を用いた。このように決定された接合要素の特性 を用いることにより，引き抜き試験で示された劣化特性 を解析に反映できる.

一方，縦ひびわれによる付着の劣化は， $\tau-\gamma$ 関係を ひびわれ面で伝達されるせん断応力とひずみの関係とみ なすことにより表現ができる．この場合，奥行き方向の 接合要素の厚さは, RC ばり供試体の厚さとみなされる. ここで, 縦ひびわれによる付着劣化に対応した接合要素 の特性も上述に示したような方法で決定するのが望まし いが，2. で示した付着試験結果だけからではその決定 は困難である.そこで $\tau-\gamma$ 関係については式（2）に 準ずると仮定し， $\tau_{\max }$ としては，実験で得られたひび われ面におけるせん断強度 $\tau_{\max }=0.58 \mathrm{MPa}(5.9 \mathrm{kgf} /$ $\left.\mathrm{cm}^{2}\right)$ を用いることとした。 なお，定数 $G$ についてもせ ん断強度と同様にひびわれ面では健全なコンクリートに 比べて低下していることが推定され，解析では上述の逆 解析結果を参考に $G=78.4 \mathrm{MPa}\left(800 \mathrm{kgf} / \mathrm{cm}^{2}\right)$ を用い ることとした。このようにして，実験で示されたひびわ れ面における応力伝達の欠如を接合要素を用いて表現で きる。

b）初期応力の導入 Fig.19は, 鉄筋さびの膨張 により生ずるひびわれの状況と, 図中に示した $X$ 軸上

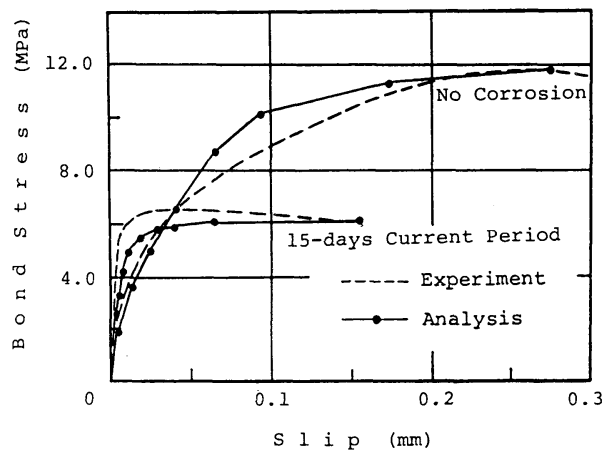

Fig. 18 Comparison Between Experiment and Analysis for the Pull-Out Test.
における引張応力の分布を模式的に示した図であ る $^{15) ~ 17)}$. この図から, 鉄筋さびの膨張の程度が大きく なると最終的には RC ばりの底面や側面に縦ひびわれ が連なる（Fig. 19(c)）が，その途中段階においてはコ ンクリートに内部応力が導入され，ひびわれ先端部では 引張応力に近い応力が導入されることがわかる（Fig.19 (a)，(b)).この高い引張応力域は弱点部となることが 容易に推定される.このような内部応力は初期応力によ り表現できる.

上述の RC ばり中に発生する内部応力すなわち鉄筋 円周方向の引張応力の影響を解析で検討するには，図に 示したような断面における応力分布も考慮した三次元的 な解析が望ましいが，本解析で適用している二次元解析 では，鉄筋ばりの奥行き方向に特性が同じとみなされる ので，断面内の応力分布は解析には反映できない。しか し, 内部応力が腐食 RC ばりの挙動に及ぼす影響につ いての定性的な検討を行ううえでは，二次元解析でも適 用が可能であると考えられる．本解析ではこのような内 部応力は, 奥行き方向に均一な鉄筋軸直角方向に導入さ れる引張応力として表現し,初期応力として取り扱った.

Fig. 19(b) の状態を想定した場合に，角本ら ${ }^{16)}$ おび 小西ら ${ }^{17)}$ の研究を参考にすると, このような初期応力 $\sigma_{i}$ は，断面内の応力分布を $\mathrm{RC}$ ばりの奥行き方向に平均 化して評価すると $\sigma_{i}=0.59 \mathrm{MPa}\left(6 \mathrm{kgf} / \mathrm{cm}^{2}\right)$ 程度であ る.しかし,このような評価法では, 上述した弱点部と なることが推定された高い引張応力域の存在を解析で適 切に表現しているとは思えない。 そこで，解析における 初期応力の導入量として, 上述の $\sigma_{i}=0.59 \mathrm{MPa}(6$ $\left.\mathrm{kgf} / \mathrm{cm}^{2}\right)$ に加えて，それよりも高い応力である $\sigma_{i}=$ $1.18 \mathrm{MPa}\left(12 \mathrm{kgf} / \mathrm{cm}^{2}\right)$ の場合を考えることとした. なお，導入要素は，実験において腐食膨張ひびわれが鉄 筋軸より上側に進展していることが確認されている

(Fig. 6 参照) ので, Fig. 20 に示す鉄筋より上側の斜線 部の要素とし, また, 接合要素の特性は, 前述の引き抜

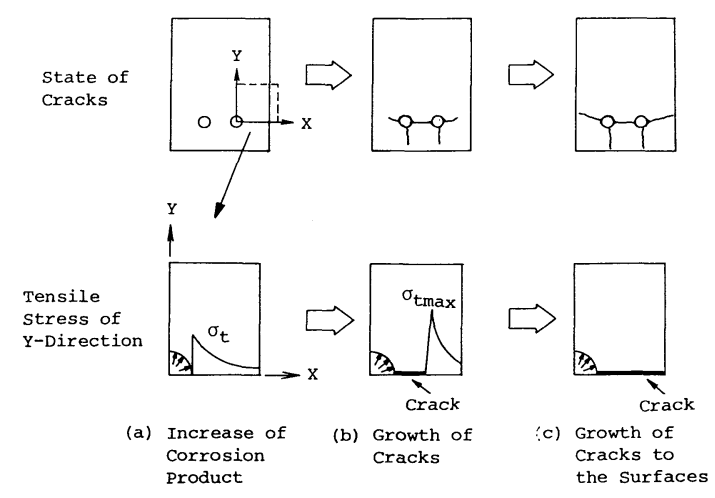

Fig. 19 The State of Tensile Stress and Cracks. 
き試験の逆解析で得られた非腐食の特性を用いることと した.

このようにしてさびの膨張圧によって生ずる内部応力 を解析で表現することができる.

\section{(2) 解析結果}

以上のように，引き抜き試験に基づいた鉄筋の付着劣 化, さびの膨張圧による内部応力, および縦ひびわれに よる鉄筋への応力伝達の欠如を表現し，それらが腐食 RC ばりの挙動に及ぼす影響について調べた。

a）鉄筋の付着劣化の影響（Case-1） 引き抜き試 験に基づいた付着劣化は前節に示したような接合要素の 特性で表現できる.その解析結果として, 荷重-スパン 中央変位関係を載荷試験の結果とともに Fig. 21 に示す。 解析結果によると, 非腐食の付着特性を用いた解析結果 は実験結果に比べると若干剛性は高いが両者はほぼ一致 しているといえよう。しかし，15 日間電食の付着特性 を用いた解析では，実験でみられた腐食 RC ばり供試 体の挙動の変化は表現することはできなかった。

したがって本解析によれば, 引き抜き試験によって得 られた付着の劣化特性では腐食 RC ばり供試体の挙動 が説明できず，鉄筋の摩擦，粘着および機械的なかみ合 いの劣化は, 直接にその挙動に及ぼす影響が少ないもの と考えられた。

b) 内部応力の影響 (Case-2) さびの膨張により， コンクリートに内部応力が導入される. 内部応力は, 前 節で示したように初期応力 $\sigma_{i}$ で表わされる. その解析

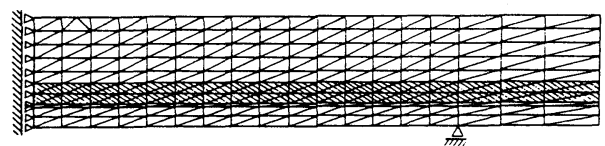

Fig. 20 Elements Introduced Initial Stress.

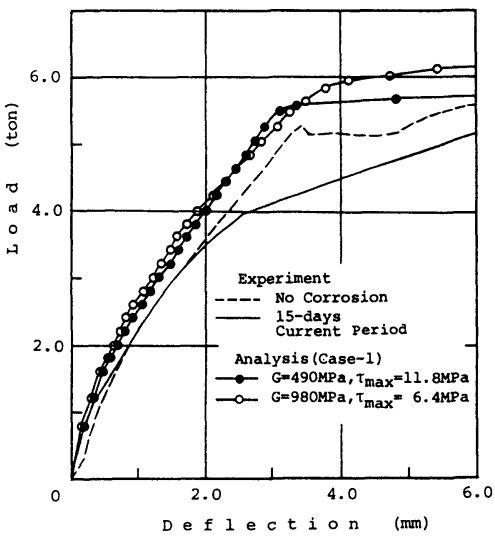

Fig. 21 Comparison Between Experiment and Analysis for the Load-Deflection Relation (Case-1).
結果をFig. 22 に示す. Fig. 22 にると, $\sigma_{i}=0.59$ $\mathrm{MPa}\left(6 \mathrm{kgf} / \mathrm{cm}^{2}\right)$ とした場合にはその影響はほとんど みられないが， $\sigma_{i}=1.18 \mathrm{MPa}\left(12 \mathrm{kgf} / \mathrm{cm}^{2}\right)$ とした場合 には実験でみられた腐食 RC ばりの剛性の低下が表現 できたといえる.このように劣化挙動が表現できたのは， 解析で初期応力を導入した要素の一部に Fig. 23(b) に 示すような鉄筋軸に沿ったひびわれが生じ，そのひびわ れによりコンクリートと鉄筋間のせん断伝達が阻害され るためであると考えられる．実際の挙動では， $\sigma_{i}=1.18$ $\mathrm{MPa}\left(12 \mathrm{kgf} / \mathrm{cm}^{2}\right)$ の場合にその劣化挙動が表現できた ことからも，Fig. 19(b) に示した高い引張応力域に上 述の鉄筋軸に沿ったひびわれが生じ，さびの膨張によっ て生じているひびわれと連なった状態で挙動するものと 考えられる。このような，ひびわれが連なり弱いせん断

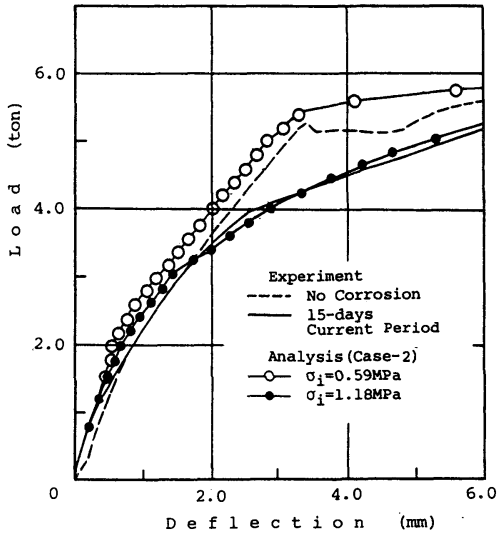

Fig. 22 Comparison Between Experiment and Analysis for the Load-Deflection Relation (Case-2).

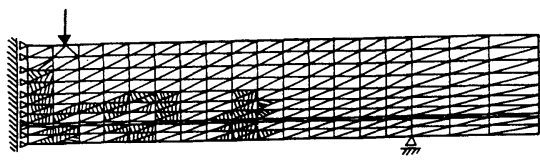

(a) Case-1 (G=490MPa, $\tau_{\max }=11.8 \mathrm{MPa}, \mathrm{P}=5.0 \mathrm{t}$ )

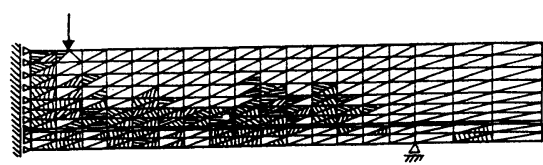

(b) Case-2 $\left(\sigma_{i}=1.18 \mathrm{MPa}, \mathrm{P}=4.0 \mathrm{t}\right)$

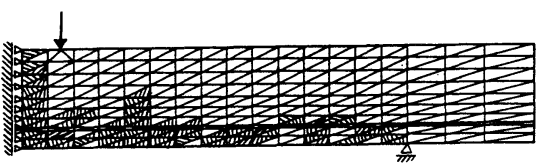

(c) Case-3 (G=78. $\left.4 \mathrm{MPa}, \tau_{\max }=0.58 \mathrm{MPa}, P=4.0 \mathrm{t}\right)$

DIAcking Area (Direction of the Crack)

Fig. 23 Failure Pattern. 
伝達面が形成された状態は, Fig. 19（c）に示したと同様 の状態であり，次に解析結果を示す縦ひびわれによる応 力伝達の欠如によっても, 腐食 RC ばりの挙動が説明 できることが推測される.

このような考察により, さびの膨張による内部応力に よって導入される縦ひびわれが弱点部となり，鉄筋への 付着せん断応力の伝達を欠如させる可能性のあることが 示され, それが腐食 $\mathrm{RC}$ ばり供試体の挙動に影響を及 ぼす要因の 1 つであることを推定できた.

c）縦ひびわれによる影響（Case-3） さびの程度 がさらに大きくなると, Fig.19(c) に示すようにひびわ れは RC ばり側面に達する。このような縦ひびわれに よる鉄筋への応力伝達の欠如は, 前節で示したような接 合要素の特性で表現ができる. その解析結果を Fig. 24 に示す. 解析值は実験でみられた荷重の増加に伴うゆる やかな剛性の低下を追跡しており, 腐食 RC ばりの劣 化挙動が表現できることがわかる．また，Fig. 23(c) に 示したひびわれ形状についても，10日間および 15 日間 電食 RC ばり供試体の特徴である曲げひびわれの進展 が鉄筋軸付近で止まる傾向も表現できた。

したがって，このような縦ひびわれによる鉄筋への付 着せん断応力の伝達の欠如が腐食 RC ばりの挙動に影 響を及ぼす要因の 1 つであることが，前述の Case-2 と 同様に推定された。

\section{（3）腐食 RC ばりの劣化挙動の要因}

腐食 RC ばりの劣化挙動に及ぼす要因について, 以 上に示したような解析的な検討を行った。その結果, 引 き抜き試験で評価される鉄筋の摩擦, 粘着および機械的 なかみ合いの劣化では, 腐食 RC ばりの劣化挙動は説 明できず，さびの膨張による内部応力や縦ひびわれの発 生に伴う鉄筋への付着せん断応力の伝達の欠如が，その 挙動に大きく影響することを推定できた。

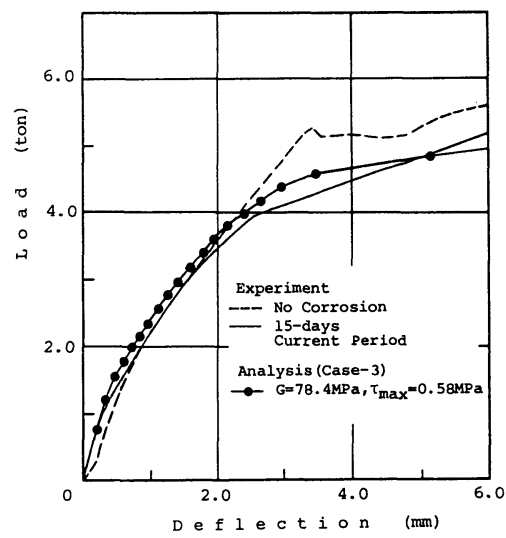

Fig. 24 Comparison Between Experiment and Analysis for the Load-Deflection Relation (Case-3).

\section{5. まと め}

鉄筋が全体的に腐食した $\mathrm{RC}$ ばりを対象として，単 鉄筋ばり供試体の載荷試験を実施したところ，腐食 RC ばりは非腐食 RC ばりに比べて耐力と剛性の低下が認 められた．このような劣化原因の推定を有限要素弾塑性 解析により行った結果, 鉄筋とコンクリート間の付着せ ん断応力の伝達の欠如をモデル化した解析で腐食 RC ばりの挙動を表現でき, この応力伝達の欠如が劣化挙動 に大きな影響を及ぼす要因の 1 つであることが推定され た.

このような付着せん断応力の伝達の欠如は，鉄筋さび の膨張により RC ばり側面方向に進展した縦ひびわれ 面によることを示唆する現象が実験で示され，この縦ひ びわれ面の発生が腐食 RC ばりの力学的な問題を論ず るうえでの 1 つの分岐点となることが示されたといえよ う. また, 縦ひびわれが RC ばりの側面にまで達して いない状態でも，腐食膨張圧により内部応力が導入され る縦ひびわれが弱点部となり，鉄筋とコンクリート間の 付着せん断応力の伝達を欠如させる可能性のあることが 示された。

このような考察は, 本研究で対象とした，せん断補強 筋であるスターラップを有しない $\mathrm{RC}$ ばりに対して適 用できるものである．2. でも述べたが，既往の実験結 果) (6) でスターラップを配してある RC ばりが腐食を受 けても大きな耐力低下が認められないという報告は, 主 鉄筋の付着性状が劣化してもスターラップにより上述の 付着せん断応力の伝達が確保されているためであると考 えられる.したがって実構造物における RC ばりでも スターラップが有効に効いていれば，静的な耐力につい ては大きな低下はないものと考えられる.

一方， RC 構造物でも版構造については，スターラッ プのようなせん断補強筋が用いられない場合が一般的で あり，特に最も過酷な荷重条件にある道路橋 $\mathrm{RC}$ 床版 などが腐食を受けた場合にその挙動が変化することが予 測され，今後検討してゆく必要があるものと考えられる。

最後に，本研究を進めるにあたり多大なご協力をいた だいた金沢大学 吉田 博教授, 川田工業（株）技術本 部中央研究室 前田研一室長, 作田孝行氏, ならびに才 リエンタルコンクリート(株)(当時・金沢大学大学院生)

角本 周氏に心から感謝の意を表します.

\section{参 考 文 献}

1）たとえば，日本コンクリート工学協会：特集・鉄筋コン クリート構造物の塩害劣化, コンクリート工学, Vol. 25, No. 11, 1987.

2）小林一輔：鋼材腐食によるコンクリート構造物の劣化機 
構, 土木施工, 25 巻 10 号, pp. 89 94, 1984.

3）魚本健人・辻 恒平・柿沢忠弘：鉄筋腐食によるコンク リート構造物の劣化機構に関する基礎的研究, 第 6 回コ ンクリート工学年次講演会論文集, pp. 173 176, 1984.

4）武若耕司・松本 進：コンクリート中の鉄筋腐食が RC 部材の力学的性状に及ぼす影響, 第 6 回コンクリート工 学年次講演会論文集, pp. 177 180, 1984.

5）岡田 清 - 小林和夫・宮川豊章 -九冨 理 : 鉄筋腐食に おける鉄筋軸方向ひびわれがコンクリート部材特性に与 える影響, 第 7 回コンクリート工学年次講演会論文集, pp. 113〜116, 1985.

6） Mirsa, S. and Uomoto, T. : 鉄筋腐食が鉄筋コンク リートはりの静的耐力に及ぼす影響, コンクリート工学 年次論文報告集, 第 9 巻, pp. 675 680, 1987.

7) Mirsa, S. and Uomoto, T. : A Study on Structural Implications of Reinforcement. corrosion, 土木学会第 42 回年次学術講演会概要集, 第 5 部, pp. 408 409, 1987.

8）小柳 洽・六郷恵哲・内田裕市：コンクリートの破壊現 象の安定性とその計測, コンクリート工学, Vol. 20, No. 6, pp. 83 89, 1982.

9) Ferguson, P.M. and Turpin, R. D. and Timpson, J. N. : Minimum Bar Spacing as a Function of Bond and Shear Strength, J. of ACI, pp. 869 897, June, 1954.

10）森永 繁: 塩害とひびわれ, セメント・コンクリート, No. 451, pp.110 117, 1984.
11) Chen, A. C. T. and Chen, W.F. : Constitutive Relation for Concrete, Proc. of ASCE, Vol.101, No. EM4, pp. 465 481, 1975.

12) von Mieses, R. : Mechanik der plastishen Form anderung von Kristallen, Zeitschrift fur Angewandte Mathematik und Mechanik (ZAMM), Vol.18, pp.161 185, 1928.

13) Goodman, R.E. and Taylor, R. L. and Brekke, T.L. : A Model for the Mechanics of Jointed Rock, Proc. of ASCE, Vol.94, No.SM3, pp.637 659, 1968.

14）暒川康男・橘 吉宏・吉田 博：骨材-モルタル平面モデ ルを用いたコンクリートの変形挙動, 土木学会論文集, 第 356 号 / I-3, pp. 369 377, 1985.

15）森川雅行・関 博・奥村 隆：鉄筋の腐食膨張による ひびわれの発生機構に関する基礎的研究, 土木学会論文 集, 第 378 号 /V -6, pp. 97〜105, 1987.

16）角本 周・暒川康男・橘 吉宏：鉄筋の腐食膨張挙動に 関する弾塑性解析, 土木学会第 42 回年次学術講演会概要 集, 第 5 部, pp. 404 405, 1987.

17）小西裕一郎・関 博・松井邦人・松島 学: 鉄筋の䳸 食膨張によるコンクリートのひびわれの有限要素解析, 土木学会第 42 回年次学術講演会概要集, 第 5 部, pp. 406 407, 1987.

(1988.5.17 • 受付) 